\title{
Long Non-coding RNA RMRP in the Pathogenesis of Human Disorders
}

\author{
Bashdar Mahmud Hussen', Tahereh Azimi², Hazha Jamal Hidayat ${ }^{3}$, Mohammad Taheri** \\ and Soudeh Ghafouri-Fard ${ }^{2 *}$ \\ ${ }^{1}$ Department of Pharmacognosy, College of Pharmacy, Hawler Medical University, Erbil, Iraq, ${ }^{2}$ Department of Medical \\ Genetics, Shahid Beheshti University of Medical Sciences, Tehran, Iran, ${ }^{3}$ Department of Biology, College of Education, \\ Salahadddin University-Erbil, Erbil, Iraq, ${ }^{4}$ Urology and Nephrology Research Center, Shahid Beheshti University of Medical \\ Sciences, Tehran, Iran
}

\section{OPEN ACCESS}

Edited by:

Palmiro Poltronieri,

Institute of Sciences of Food

Production, Italian National Research

Council, Italy

Reviewed by:

Svetlana Vakkilainen,

National Cancer Institute, National

Institutes of Health (NIH),

United States

Ammad Ahmad Faroogi,

Institute of Biomedical and Genetic

Engineering (IBGE), Pakistan

*Correspondence:

Mohammad Taher

Mohammad_823@yahoo.com

Soudeh Ghafouri-Fard

s.ghafourifard@sbmu.ac.ir

Specialty section:

This article was submitted to

Molecular and Cellular Oncology,

a section of the journal

Frontiers in Cell and Developmental

Biology

Received: 05 March 2021

Accepted: 12 April 2021

Published: 30 April 2021

Citation:

Hussen BM, Azimi T, Hidayat HJ,

Taheri M and Ghafouri-Fard S (2021)

Long Non-coding RNA RMRP in

the Pathogenesis of Human

Disorders.

Front. Cell Dev. Biol. 9:676588. doi: $10.3389 /$ fcell.2021.676588
RNA component of mitochondrial RNA processing endoribonuclease (RMRP) is a non-coding transcript firstly acknowledged for its association with the cartilage-hair hypoplasia $(\mathrm{CHH})$ syndrome, a rare autosomal recessive condition. This transcript has been spotted in both nucleus and mitochondria. In addition to its role in the pathogenesis of $\mathrm{CHH}$, RMRP participates in the pathogenesis of cancers. Independent studies in bladder cancer, colon cancer, hepatocellular carcinoma, lung cancer, breast carcinoma and multiple myeloma have confirmed the oncogenic effects of RMRP. Mechanistically, RMRP serves as a sponge for some miRNAs such as miR-206, miR613, and miR-217. In addition to these miRNAs, expressions of tens of miRNAs have been altered following RMRP silencing, implying the vast extent of RMRP/miRNA network. In the present narrative review, we explain the role of RMRP in the development of cancers and some other non-malignant disorders.

Keywords: long non-coding RNA RMRP, cancer, expression, biomarkers, cell lines

\section{INTRODUCTION}

Although protein-coding genes comprise a minor portion of the mammalian genome, it has been revealed that the vast majority of these genomes is transcribed at some level (Carninci et al., 2005; Birney et al., 2007). It has also been speculated that considerable portion of these transcripts are likely functional (Mattick et al., 2010). Notably, the ENCODE consortium has described assignment of "biochemical functions" to approximately $80 \%$ of the genome (Consortium, 2012). This group of non-coding RNAs (ncRNAs) includes several members ranging from the lately described abundant ribosomal RNAs (rRNAs) (Stark et al., 1978), small nuclear RNAs (snRNAs) and small nucleolar RNAs (snoRNAs) to those with recently appreciated regulatory RNAs, namely microRNAs (miRNAs) and long non-coding RNAs (lncRNAs) (Palazzo and Lee, 2015). miRNAs have sizes about 22 nucleotides and regulate expression of genes mostly through binding with $3^{\prime}$ untranslated regions of target transcripts (Macfarlane and Murphy, 2010). LncRNAs have sizes over 200 nucleotides and are transcribed by RNA Polymerase (RNA Pol) II and RNA Pol III. They modulate numerous cellular processes including histone modification, DNA methylation, and transcription of genes through modulating chromatin configuration and DNA accessibility (Dahariya et al., 2019). 
RNA component of mitochondrial RNA processing endoribonuclease (RMRP) is a transcript with wide expression in diverse tissues obtained from human and mice species (Rosenbluh et al., 2011). RMRP has a regulatory role in the processing of RNA in both mitochondrial and ribosomal compartments (Hermanns et al., 2005). RMRP transcripts have been detected in both mitochondria and nucleus (Chang and Clayton, 1987; Rosenbluh et al., 2011). This lncRNA has a remarkable role in the primary stages of mice development (Rosenbluh et al., 2011). In humans, mutations in the RMRP gene has been associated with cartilage-hair hypoplasia $(\mathrm{CHH})$ syndrome, a multi-systemic disorder that is inherited via an autosomal recessive mode. Clinical characteristics of $\mathrm{CHH}$ are unbalanced short stature, fine and scant hair, defects in cellular immunity and susceptibility to cancer which are related to defects in expression of RMRP (Hermanns et al., 2005). Although immunodeficiency is a possible underlying mechanism of malignancy in these patients, many $\mathrm{CHH}$ cases with no history of immunodeficiency has developed neoplastic conditions such as lymphoma, implying a multifactorial basis for development of malignancy in $\mathrm{CHH}$ (Vakkilainen et al., 2019b). Epstein-Barr virus infection can explain some cases of lymphoproliferative diseases in $\mathrm{CHH}$ (Taskinen et al., 2013; Sathishkumar et al., 2018). Yet, not all lymphoproliferative disorders are related with this virus (Nguyen et al., 1718). In addition to defects in response to viral infections, chromosomal instability (Hauck et al., 2018) and impaired telomere function (Kostjukovits et al., 2017) might explain the increased risk of malignancy in $\mathrm{CHH}$. A high throughput expression assay in $\mathrm{CHH}$ fibroblasts has shown abnormal expression of tens of gene. Notably, under-expressed genes have been functionally associated with cell cycle. Moreover, regulatory pathways of apoptosis, bone and cartilage development, and functions of lymphocyte, and PI3K-Akt cascade have been among other dysregulated mechanisms. $\mathrm{CHH}$ cells have exhibited delays in the transition from G2 stage to mitosis (Vakkilainen et al., 2019a). Experiment in Zebrafish model of $\mathrm{CHH}$ produced by Rmrp knock-down has verified the role of over-activation of $\mathrm{Wnt} / \beta$-Catenin signaling in disruption of chondrogenesis and bone ossification (Sun et al., 2019). Although RMRP has been shown to bind with the mitochondrial RNA processing complex RNase MRP (Chang and Clayton, 1987), there is no obvious mitochondrial deficiencies in $\mathrm{CHH}$ patients. In conjunction with hTERT, RMRP can make an RNA dependent RNA polymerase which transforms single stranded RMRP transcript into double stranded form (Maida et al., 2009). Over-expression of RMRP has been demonstrated in a wide spectrum of human malignancies (Tang et al., 2019). In the present narrative review, we explain the role of RMRP in the development of cancers and some other non-malignant disorders.

\section{MALIGNANT CONDITIONS}

\section{Cell Line Studies}

In the cholangiocarcinoma cells, up-regulation of RMRP is associated with down-regulation of miR-217, a miRNA that is sequestered by RMRP (Tang et al., 2019). RMRP silencing has resulted in up-regulation of several miRNAs such as hsa-miR33a-3p, hsa-miR-186-5p, and hsa-miR-216a-5p, while downregulation of hsa-miR-345-5p, hsa-miR-1275, and hsa-miR-4454 (Tang et al., 2019). RMRP silencing can suppress proliferation of cholangiocarcinoma cells, stimulate apoptosis in these cells, and block them in the G0/G1 stage (Tang et al., 2019). In lung cancer cells, RMRP silencing evidently reserved cell proliferation, migration, and invasiveness, while blocking cell cycle transition. miR-1-3p has been identified as a target of RMRP in these cells (Tang et al., 2019). Figure 1 displays the mechanism of RMRPmediated oncogenesis in lung cancer.

In the bladder cancer cell lines, RMRP can enhance proliferation, migration potential and invasiveness of cells through modulating expression of miR-206 (Cao et al., 2019), a tumor suppressor miRNA that induces cell cycle arrest (Huang et al., 2016). Based on the presence of the $\beta$-catenin/TCF and YAP/TBX5 constituents in the upper parts of the RMRP gene, expression of RMRP might be associated with the cancerassociated pathways, Wnt/ $\beta$-catenin and Hippo/YAP. Functional studies have shown that induction of Wnt signaling enhances expression of RMRP via $\beta$-catenin and YAP nuclear factors (Park and Jeong, 2015). In hepatocellular carcinoma cells, RMRP silencing has precluded cell proliferation, migration and invasive properties, while stimulating cell cycle arrest. These effects are mediated by sponging miR-613 (Zhou et al., 2019). Another study in this type of cancer has shown the role of RMRP in sequestration of miR-206 and activation of TACR1/Erk1/2 pathway (Hongfeng et al., 2020). However, Shao et al. (2020) have demonstrated down-regulation of RMRP in the hepatocellular carcinoma cells. Enforced overexpression of RMRP in these cells enhanced apoptosis rate of these cells through modulating miR-766 expression (Shao et al., 2020). RMRP silencing in gastric cancer cells suppresses cell proliferation via modulation of miR-206 and subsequent regulation of cell cycle transition through modulation of Cyclin D2 (Shao et al., 2016). In the neuroblastoma cells, the oncogenic effects of RMRP are mediated through sequestering miR-206 and enhancing expression of TACR1 (Pan et al., 2019). In the papillary thyroid carcinoma cells, expression of RMRP has been increased while expression of miR-675 has been diminished. MAPK1 has been identified as a target of miR-675 in these cells (Wang et al., 2019). A brief review of investigations that appraised RMRP expression in cancer-derived cell lines is presented in Table 1.

\section{Animal Studies}

In vivo assays have verified the cancer-promoting effects of RMRP. RMRP silencing has attenuated tumorigenesis process in xenograft model of liver cancer through modulation of miR-613 expression (Zhou et al., 2019). However, another in vivo study demonstrated the opposite role for RMRP in the pathogenesis of hepatocellular carcinoma through modulation of miR-766 (Shao et al., 2020). RMRP silencing has decreased the rate of growth of cholangiocarcinoma in animal models in association with the frequency of Ki-67positivite cells in these tumors (Tang et al., 2019). In the 


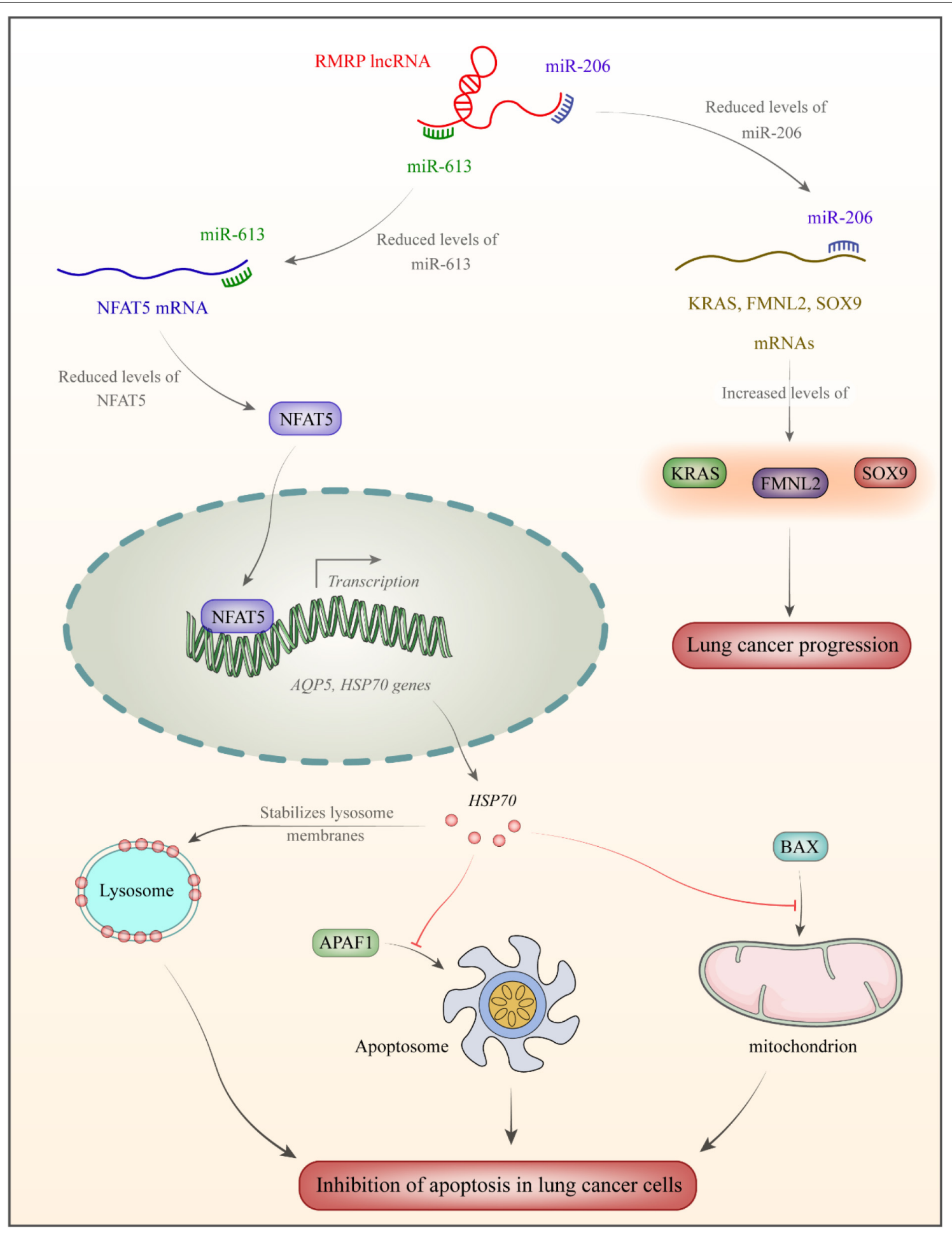

FIGURE 1 | RMRP has been over-expressed in lung cancer (Shao et al., 2016). This IncRNA acts as a sponge for miR-613 and miR-206. miR-206 binds with 3'UTR of NFAT5 transcription factor (Yang et al., 2020). This transcription factor increases expression of AQP5 (Guo and Jin, 2015) and the heat shock protein HSP70 which increases stability of lysosome membrane (Boya and Kroemer, 2008). As a member of HSP family, it is produced following exposure to cellular stressful situations such as excessive heat/cold, ultraviolet light and in the course of wound healing or tissue remodeling. HSP70 have chaperone functions through stabilizing proteins to certify correct folding or assisting in protein refolding (Rosenzweig et al., 2019). Moreover, HSP70 inhibits APAF1 binding with apoptosome and suppresses BAX binding to mitochondria, thus decreasing apoptosis rate in lung cancer cells (Wu et al., 2017). miR-206 binds with 3'UTR of SOX9, FMNL2, and KRAS. Down-regulation of miR-206 enhances protein levels of these genes in lung cancer (Shao et al., 2016). 
TABLE 1 | Brief results of studies which gauged expression of RMRP in cancerous cell lines ( $\Delta$ : knock-down).

\begin{tabular}{|c|c|c|c|c|}
\hline Cancer types & $\begin{array}{l}\text { Targets/regulators and } \\
\text { signaling pathways }\end{array}$ & Assessed cell lines & Function & References \\
\hline Bladder cancer & miR-206 & $\begin{array}{l}\text { BIU-87, T24, and } \\
\text { SV-HUC-1 }\end{array}$ & $\begin{array}{l}\triangle \mathrm{RMRP}: \downarrow \text { cell proliferation, } \\
\text { migration, and invasion }\end{array}$ & Cao et al. (2019) \\
\hline Colorectal cancer & $\begin{array}{l}\text { Wnt and Hippo signaling } \\
\text { pathways } \\
(\beta \text {-catenin/YAP/TBX5) }\end{array}$ & $\begin{array}{l}\text { SW480, HT-29, HCT116, } \\
\text { HEK293, HEK293T, and } \\
\text { Beas-2B }\end{array}$ & - & Park and Jeong (2015) \\
\hline \multirow[t]{3}{*}{ Hepatocellular carcinoma } & miR-613 & $\begin{array}{l}\text { Hep3B, HCCLM3, and } \\
\text { HL-7702 }\end{array}$ & $\begin{array}{l}\triangle \mathrm{RMRP}: \downarrow \text { cell proliferation, } \\
\text { migration, and invasion }\end{array}$ & Zhou et al. (2019) \\
\hline & miR-206/TACR1 & $\begin{array}{l}\text { SMMC-7721, Bel-7402, } \\
\text { MHCC-97, HepG2, Hep3B, } \\
\text { Huh-7, and HL- } 7702\end{array}$ & $\begin{array}{l}\Delta \text { RMRP: } \downarrow \text { cell proliferation, } \\
\text { migration, invasion, and } \uparrow \\
\text { apoptosis }\end{array}$ & Hongfeng et al. (2020) \\
\hline & miR-766 & $\begin{array}{l}\text { Hep3B, HepG2, } \\
\text { MHCC97H, HuH7, and } \\
\text { HL-7702 }\end{array}$ & $\begin{array}{l}\uparrow \mathrm{RMRP}: \downarrow \text { cell proliferation, } \\
\text { migration, invasion, and } \uparrow \\
\text { apoptosis }\end{array}$ & Shao et al. (2020) \\
\hline Cholangiocarcinoma & $\operatorname{miR}-217$ & HCCC-9810 and RBE & $\begin{array}{l}\Delta \text { RMRP: } \downarrow \text { cell proliferation, } \\
\text { migration, invasion and } \uparrow \\
\text { apoptosis }\end{array}$ & Tang et al. (2019) \\
\hline Gastric cancer & miR-206/Cyclin D2 & $\begin{array}{l}\text { AGS, BGC-823, HGC-27, } \\
\text { MGC-803, SGC-7901, and } \\
\text { GES-1 }\end{array}$ & $\begin{array}{l}\Delta \mathrm{RMRP}: \downarrow \text { cell proliferation } \\
\text { and } \uparrow \text { apoptosis }\end{array}$ & Shao et al. (2016) \\
\hline Glioma & - & U87 and U251 & $\begin{array}{l}\Delta \text { RMRP: } \downarrow \text { cell proliferation, } \\
\text { migration, invasion, and } \uparrow \\
\text { apoptosis }\end{array}$ & Feng et al. (2017) \\
\hline Neuroblastoma & $\begin{array}{l}\text { miR-206/TACR1 and } \\
\text { ERK1/2 pathway }\end{array}$ & $\begin{array}{l}\text { NB-1, SK-N-AS, and } \\
\text { HEK293T }\end{array}$ & $\begin{array}{l}\triangle \mathrm{RMRP}: \downarrow \text { cell proliferation, } \\
\text { migration, and invasion }\end{array}$ & Pan et al. (2019) \\
\hline \multirow[t]{3}{*}{ Non-small cell lung cancer } & $\begin{array}{l}\text { miR-206/KRAS, FMNL2 } \\
\text { and SOX9 }\end{array}$ & $\begin{array}{l}\text { A549, SPC-A1, H1299, } \\
\mathrm{H} 23 \text {, and } 16 \mathrm{HBE}\end{array}$ & $\begin{array}{l}\uparrow \mathrm{RMRP}: \uparrow \text { cell proliferation, } \\
\text { colony formation, and invasion }\end{array}$ & Shao et al. (2016) \\
\hline & miR-613/NFAT5 & $\begin{array}{l}\text { HCC827, 16HBE, H1299, } \\
\text { H1975, A549, and HCT116 }\end{array}$ & $\begin{array}{l}\triangle \mathrm{RMRP}: \downarrow \text { cell proliferation, } \\
\text { migration, and invasion }\end{array}$ & Yang et al. (2020) \\
\hline & miR-1-3p/ANXA2 & $\begin{array}{l}\text { A549, Calu1, H1299, } \\
\text { H460, and BEAS-2B }\end{array}$ & $\begin{array}{l}\triangle \mathrm{RMRP}: \downarrow \text { cells proliferation, } \\
\text { migration and invasion }\end{array}$ & Tang et al. (2019) \\
\hline Papillary thyroid cancer & miR-675/MAPK1 & $\begin{array}{l}\text { HTH83, BCPAP, and TPC-1 } \\
\text { and HT-ori3 }\end{array}$ & $\begin{array}{l}\triangle \mathrm{RMRP}: \downarrow \text { cell proliferation, } \\
\text { migration and invasion }\end{array}$ & Wang et al. (2019) \\
\hline Multiple myeloma & miR-34a-5p/c-Myc & $\begin{array}{l}\mathrm{NCl}-\mathrm{H} 929, \mathrm{RPMI}-8226 \text { and } \\
\text { NPCs }\end{array}$ & $\begin{array}{l}\Delta \mathrm{RMRP}: \downarrow \text { cell proliferation } \\
\text { and } \uparrow \text { apoptosis }\end{array}$ & Kong et al. (2019) \\
\hline
\end{tabular}

TABLE 2 | Brief reports of studies which assessed function of RMRP in cancer animal models ( $\Delta$ : knock down or deletion).

\begin{tabular}{|c|c|c|c|}
\hline Cancer types & Animal models & Function & References \\
\hline \multirow[t]{2}{*}{ Hepatocellular carcinoma } & Male athymic Balb/c nude mice & $\Delta$ RMRP: $\downarrow$ tumor size and weight & Zhou et al. (2019) \\
\hline & Male Balb/c nude mice & $\uparrow$ RMRP: $\downarrow$ tumor volume and weight & Shao et al. (2020) \\
\hline Cholangiocarcinoma & Male nude mice & $\Delta \mathrm{RMRP}: \downarrow$ tumor volume and weight & Tang et al. (2019) \\
\hline Gastric cancer & Male BALB/c nude mice & $\Delta \mathrm{RMRP}: \downarrow$ tumor growth & Shao et al. (2016) \\
\hline Neuroblastoma & Female athymic nude mice & $\Delta \mathrm{RMRP}: \downarrow$ tumor volume and weight & Pan et al. (2019) \\
\hline Non-small cell lung cancer & Male Balb/c nude mice & $\Delta \mathrm{RMRP}: \downarrow$ tumor growth, migration and invasion & Yang et al. (2020) \\
\hline Multiple myeloma & Male BALB/c-nude mice & $\Delta$ RMRP: $\downarrow$ tumor growth & Kong et al. (2019) \\
\hline
\end{tabular}

xenograft model of gastric cancer, RMRP silencing attenuated tumor growth via modulation of miR-206 expression (Shao et al., 2016). A brief record of in vivo studies is shown in Table 2.

\section{Clinical Studies}

Cao et al. (2019) have confirmed up-regulation of RMRP in bladder cancer samples in comparison with the nearby noncancerous samples. Expression levels of RMRP have been correlated with tumor dimensions, lymph node metastasis and outcome of cancer in these patients (Cao et al., 2019). Levels of RMRP have also been up-regulated in clinical samples of colorectal and breast cancer patients (Park and Jeong, 2015). Over-expression of RMRP has also been reported in patients with hepatocellular carcinoma in correlation with tumor aggressiveness and adverse clinical outcome (Zhou et al., 2019). Accordingly, over-expression of RMRP has been identified as an indicator of poor prognosis in these patients (Hongfeng et al., 2020). In contrast with these studies, Shao et al. (2020) have reported down-regulation of RMRP in clinical 
samples obtained from patients with hepatocellular carcinoma. Under-expression of RMRP in these patients has been reported to be associated with low survival (Shao et al., 2020). RMRP expression has been increased in non-small cell lung cancer tissues in association with high clinical stage and poor patients' outcome (Tang et al., 2019). Expression of RMRP has been elevated in tissue, plasma and gastric juices obtained from patients with gastric cancer in association with Borrmann type and metastatic capacity. Notably, they reported suitability of levels of RMRP in plasma and gastric juice for diagnosis of gastric cancer (Shao et al., 2016). In the glioblastoma samples, RMRP over-expression has been associated with high tumor grade, low Karnofsky Performance Score and poor clinical outcome (Feng et al., 2017). A summary of experiments which appraised transcript levels of RMRP in clinical specimens from cancer patients is shown in Table 3.

Somatic mutations in the promoter region of this lncRNA have been firstly demonstrated in breast cancer

TABLE 3 | Outlines of studies reported expression of RMRP in cancerous clinical samples (OS: overall survival, ANTs: adjacent normal tissues).

\begin{tabular}{|c|c|c|c|c|}
\hline Cancer types & Samples & $\begin{array}{l}\text { Expression (tumor } \\
\text { vs. normal) }\end{array}$ & Kaplan-Meier analysis & References \\
\hline Bladder cancer & $\begin{array}{l}91 \text { paired of BC tissues and } \\
\text { adjacent tissues }\end{array}$ & Up & $\begin{array}{l}\text { Lower RMRP expression } \\
\text { correlated with better prognosis. }\end{array}$ & Cao et al. (2019) \\
\hline Colorectal cancer (CRC) & $\begin{array}{l}8 \text { paired of CRC tissues and } \\
\text { ANTs }\end{array}$ & Up & - & Park and Jeong (2015) \\
\hline \multirow[t]{3}{*}{ Hepatocellular carcinoma (HCC) } & $\begin{array}{l}52 \text { paired of HCC tissues and } \\
\text { ANTs }\end{array}$ & Up & $\begin{array}{l}\text { Higher RMRP expression levels } \\
\text { correlated with shorter OS in } \\
\text { HCC patients compared with } \\
\text { lower group. }\end{array}$ & Zhou et al. (2019) \\
\hline & $\begin{array}{l}42 \text { paired of HCC tissues and } \\
\text { matched normal tissues }\end{array}$ & Up & $\begin{array}{l}\text { RMRP high expression levels } \\
\text { associated with decrease of OS } \\
\text { rate in HCC patients. }\end{array}$ & Hongfeng et al. (2020) \\
\hline & $\begin{array}{l}40 \text { paired of HCC tissues and } \\
\text { ANTs }\end{array}$ & Down & $\begin{array}{l}\text { High RMRP expression levels } \\
\text { correlated with better } 5 \text {-years and } \\
\text { median survival rates in HCC } \\
\text { patients. }\end{array}$ & Shao et al. (2020) \\
\hline Cholangiocarcinoma (CCA) & $\begin{array}{l}33 \text { paired of CCA tissues and } \\
\text { ANTs }\end{array}$ & Up & $\begin{array}{l}\text { Patients with lower RMRP } \\
\text { expression levels had longer OS. }\end{array}$ & Tang et al. (2019) \\
\hline Gastric cancer (GC) & $\begin{array}{l}132 \text { paired of GC and } \\
\text { non-tumorous tissues }\end{array}$ & Up & - & Shao et al. (2016) \\
\hline Glioma & $\begin{array}{l}39 \text { glioma tissues and } 11 \\
\text { normal brain tissues }\end{array}$ & Up & $\begin{array}{l}\text { Higher RMRP expression levels } \\
\text { correlated with poorer OS in } \\
\text { glioma patients than that of the } \\
\text { lower group. }\end{array}$ & Feng et al. (2017) \\
\hline Neuroblastoma & $\begin{array}{l}44 \text { paired of neonatal } \\
\text { neuroblastoma tissues and } \\
\text { ANTs }\end{array}$ & Up & $\begin{array}{l}\text { Higher RMRP expression levels } \\
\text { associated with poor prognosis in } \\
\text { neonatal neuroblastoma patients. }\end{array}$ & Pan et al. (2019) \\
\hline \multirow[t]{4}{*}{ Non-small cell lung cancer (NSCLC) } & $\begin{array}{l}\text { Plasma specimens from } 63 \\
\text { NSCLC patients and } 33 \\
\text { cancer-free smoker individuals }\end{array}$ & Up & - & Lin et al. (2018) \\
\hline & $\begin{array}{l}35 \text { paired of lung } \\
\text { adenocarcinoma tissues and } \\
\text { ANTs }\end{array}$ & Up & - & Shao et al. (2016) \\
\hline & $\begin{array}{l}80 \text { paired of NSCLC tissues } \\
\text { and ANTs }\end{array}$ & Up & $\begin{array}{l}\text { RMRP high expression levels } \\
\text { associated with decrease of OS } \\
\text { rate in NSCLC patients. }\end{array}$ & Yang et al. (2020) \\
\hline & $\begin{array}{l}38 \text { paired of NSCLC tissues } \\
\text { and ANTs }\end{array}$ & Up & $\begin{array}{l}\text { Higher RMRP expression levels } \\
\text { correlated with poorer OS in } \\
\text { NSCLC patients compared to } \\
\text { lower group. }\end{array}$ & Tang et al. (2019) \\
\hline Breast cancer (BC) & $\begin{array}{l}8 \text { paired of } B C \text { tissues and } \\
\text { ANTs }\end{array}$ & Up & - & Park and Jeong (2015) \\
\hline Papillary thyroid cancer (PTC) & $\begin{array}{l}57 \text { paired of PTC tissues and } \\
\text { ANTs }\end{array}$ & Up & - & Wang et al. (2019) \\
\hline Multiple myeloma (MM) & $\begin{array}{l}\text { Bone marrow specimens from } \\
28 \text { MM patients and } 10 \text { healthy } \\
\text { donors }\end{array}$ & Up & $\begin{array}{l}\text { High RMRP expression levels } \\
\text { correlated with shorter } \\
\text { disease-free survival and OS in } \\
\text { MM patients. }\end{array}$ & Kong et al. (2019) \\
\hline
\end{tabular}


(Rheinbay et al., 2017). The hotspot mutation region in this study has been further assessed in another cohort of patients with diverse types of cancers showing the presence of RMRP promoter mutations in two gastric cancer samples, a colon carcinoma sample and a sarcoma. Notably, none of these mutations has been formerly reported in breast cancers (Son et al., 2020). Table 4 shows the diverse mutations identified in the promoter region of RMRP in different solid and hematologic tumors.

\section{Non-malignant Disorders}

Han et al. (2020) have assessed the role of RMRP in lipopolysaccharide (LPS)-associated sepsis. They reported down-regulation of RMRP following LPS exposure. This downregulation has been accompanied by significant reductions in MMP and mitochondrial cytochrome C levels, increased cardiomyocyte apoptosis, over-production of reactive oxygen species, up-regulation of cytochrome $\mathrm{C}$ in the cytoplasmic compartment, and over-production of caspase- 3 and caspase9 and NF- $\kappa$ B p65 subunit. Their in vivo experiments also verified the role of RMRP in the suppression of LPS-associated apoptosis and mitochondrial defects through sponging of

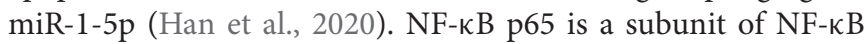
transcription complexes (Sun, 2011). In fact, NF- $\kappa$ B family includes several transcription factors regulating expression of genes that partake in numerous crucial physiological responses including inflammatory reactions, cell proliferation, differentiation, cell adhesion and apoptosis (Karin et al., 2002). Thus, the regulatory role of RMRP on NF- $\mathrm{RB}$ p65 subunit potentiates this lncRNA as a contributor in many physiological and pathological processes.
An et al. (2020) have reported up-regulation of RMRP and Gadd45g in coronary atherosclerosis and human vascular smooth muscle cells, whereas miR-128-1-5P expression was decreased in these cells. RMRP silencing suppressed IL- 6 and IL-8 production, and attenuated expression of apoptosis related proteins in these cells following ox-LDL treatment (An et al., 2020). Previous studies have indicated up-regulation of GADD45G in response to stressful growth arrest situations and exposure to DNAdamaging substances. In fact, GADD45G has an important role in response to environmental stress through facilitating activation of the p38/JNK pathway (Takekawa and Saito, 1998). Moreover, GADD45G has been shown to be regulated by NF$\kappa \mathrm{B}$ (Tamura et al., 2012). Thus, the interaction between RMRP, GADD45G and NF-кB might be involved in a wide variety of human disorders.

Expression of RMRP has also been increased in the model of ischemic cerebral injury. Notably, valproate has an inhibitory effect on RMRP expression, while increasing PI3K/Akt activity leading to enhancement of cell viability and attenuation of apoptosis ( $\mathrm{Li}$ and Sui, 2020). Up-regulation of RMRP has also been observed in a number of immune-related conditions. For instance, RMRP expression has been increased in $\mathrm{T}$ cells of patients with rheumatoid arthritis in correlation with disease duration (Moharamoghli et al., 2019). Finally, expression of RMRP has been significantly down-regulated in patients with major depressive disorder compared with normal individuals in correlation with severity of depression. Besides, RMRP levels were decreased in an animal model of depression (Seki et al., 2019). Table 5 reviews the role of RMRP in non-cancerous pathologic conditions.

TABLE 4 | Summary of studies that have analyzed RMRP promoter mutations in solid and hematologic tumors.

\begin{tabular}{|c|c|c|c|c|c|c|}
\hline Type of cancers & Number of tumors & Wild type & Mutation & Location & Mutation (\%) & References \\
\hline Gastric carcinoma & 230 & 228 & 2 & $\begin{array}{l}\text { Chr9:35,658,037dupA } \\
\text { Chr9: 35,658,174dupT }\end{array}$ & 0.9 & Son et al. (2020) \\
\hline Colorectal carcinoma & 388 & 387 & 1 & Chr9:35,658,167G > T & 0.3 & Son et al. (2020) \\
\hline Sarcoma & 70 & 69 & $\begin{array}{l}1 \text { (malignant } \\
\text { fibrous } \\
\text { histiocytoma) }\end{array}$ & $\begin{array}{l}\text { Chr9.35,658,015_35,658,031 } \\
\text { dupCACGTCCTCAGCTTCAC } \\
\text { (17 bp) }\end{array}$ & 1.4 & Son et al. (2020) \\
\hline Breast cancer & 360 & - & - & $\begin{array}{l}\text { Chr9:35658033 G > A } \\
\text { Chr9:35658043 T > G }\end{array}$ & - & Rheinbay et al. (2017) \\
\hline Adulthood AML & 200 & 199 & $\begin{array}{l}1 \text { (AML with } \\
\text { multilineage } \\
\text { dysplasia) }\end{array}$ & $\begin{array}{l}\text { g.35,658,020_35,658,039 } \\
\text { dup } \\
\text { CCTCAGCTTCACAGAGTAGT } \\
\text { (20 bp) }\end{array}$ & 0.5 & Son et al. (2019) \\
\hline Adulthood ALL & 150 & 149 & 1 (B-ALL) & $\begin{array}{l}\text { g.35,658,017_35,658,037 } \\
\text { dup } \\
\text { CGTCCTCAGCTTCACAGAGTA } \\
\text { ( } 21 \text { bp) }\end{array}$ & A & Son et al. (2019) \\
\hline Childhood ALL & 200 & 199 & 1 (B-ALL) & $\begin{array}{l}\text { g.35,658,029_35,658,041 } \\
\text { dupCACAGAGTAGTAT } \\
\text { (13 bp) }\end{array}$ & 0.5 & Son et al. (2019) \\
\hline Multiple myeloma & 75 & 74 & 1 & $\begin{array}{l}\text { g.35,658,015_35,658,031 } \\
\text { dup } \\
\text { CACGTCCTCAGCTTCAC } \\
\text { (17 bp) }\end{array}$ & 0 & Son et al. (2019) \\
\hline
\end{tabular}


TABLE 5 | Summary of RMRP studies in non-cancerous pathologic conditions.

\begin{tabular}{|c|c|c|c|c|c|c|}
\hline $\begin{array}{l}\text { Pathologic } \\
\text { conditions }\end{array}$ & Clinical samples & Cell lines & Animal models & $\begin{array}{l}\text { Targets/regulators } \\
\text { and signaling } \\
\text { pathways }\end{array}$ & Results & References \\
\hline $\begin{array}{l}\text { Sepsis (myocardial } \\
\text { dysfunction) }\end{array}$ & - & $\begin{array}{l}\text { Murine HL-1 } \\
\text { cardiomyocytes }\end{array}$ & Male C57B6/L mice & miR-1-5p/HSPA4 & $\begin{array}{l}\text { RMRP regulated } \\
\text { cardiomyocyte apoptosis } \\
\text { and inhibited } \\
\text { Lipopolysaccharide- } \\
\text { induced } \\
\text { sepsis. }\end{array}$ & $\begin{array}{l}\text { Han et al. } \\
(2020)\end{array}$ \\
\hline Atherosclerosis & - & $\begin{array}{l}\text { Human vascular } \\
\text { smooth muscle } \\
\text { cells, HEK293T }\end{array}$ & Wistar rats & $\begin{array}{l}\text { miR-128-1- } \\
\text { 5P/Gadd45g }\end{array}$ & $\begin{array}{l}\text { RMRP was upregulated in } \\
\text { coronary atherosclerosis. } \\
\text { Its downregulation } \\
\text { associated with inhibition of } \\
\text { IL-6, IL-8, and apoptosis } \\
\text { related proteins. }\end{array}$ & An et al. (2020) \\
\hline $\begin{array}{l}\text { Ischemic heart } \\
\text { failure }(\mathrm{HF})\end{array}$ & $\begin{array}{l}\text { PBMC and left } \\
\text { ventricle biopsies of } \\
18 \text { non-end-stage } \\
\text { dilated ischemic } \\
\text { cardiomyopathy } \\
\text { and } 17 \text { controls/11 } \\
\text { post-ischemic } \\
\text { end-stage HF } \\
\text { patients }\end{array}$ & - & $\begin{array}{l}\text { C57BL/6 J male } \\
\text { mice }\end{array}$ & - & $\begin{array}{l}\text { RMRP was dysregulated in } \\
\text { both end- and } \\
\text { non-end-stage HF patients } \\
\text { and mouse model of } \\
\text { cardiac hypertrophy. }\end{array}$ & $\begin{array}{l}\text { Greco et al. } \\
(2016)\end{array}$ \\
\hline $\begin{array}{l}\text { Ischemic } \\
\text { myocardial injury }\end{array}$ & - & $\mathrm{H} 9 \mathrm{c} 2$ & $\begin{array}{l}\text { Sprague-Dawley } \\
\text { male rats }\end{array}$ & $\begin{array}{l}\text { miR-206/ATG3 and } \\
\text { PI3K/AKT/mTOR } \\
\text { pathway }\end{array}$ & $\begin{array}{l}\text { RMRP downregulation } \\
\text { enhanced cardiac function } \\
\text { and suppressed apoptosis } \\
\text { followed by myocardial I/R } \\
\text { injury. }\end{array}$ & $\begin{array}{l}\text { Kong et al. } \\
\text { (2019) }\end{array}$ \\
\hline Cardiac fibrosis & - & - & $\begin{array}{l}\text { pathogen-free } \\
\text { Sprague-Dawley } \\
\text { rats }\end{array}$ & miR-613 & $\begin{array}{l}\text { RMRP was upregulated in } \\
\text { cardiac fibrosis. Its } \\
\text { reduction led to inhibition of } \\
\text { cardiac proliferation, } \\
\text { differentiation and collagen } \\
\text { accumulation. }\end{array}$ & $\begin{array}{l}\text { Zhang et al. } \\
(2019)\end{array}$ \\
\hline Ischemic stroke (IS) & - & $\mathrm{BV}-2$ & $\begin{array}{l}\text { Adult male } \\
\text { C57BL/6 mice }\end{array}$ & $\begin{array}{l}\text { PI3K/Akt signaling } \\
\text { pathway }\end{array}$ & $\begin{array}{l}\text { Valproate inhibited RMRP } \\
\text { expression, which } \\
\text { increased survival rates and } \\
\text { modulated cell apoptosis. }\end{array}$ & $\begin{array}{l}\text { Li and Sui } \\
\text { (2020) }\end{array}$ \\
\hline $\begin{array}{l}\text { Multiple sclerosis } \\
\text { (MS) }\end{array}$ & $\begin{array}{l}\text { Whole venous } \\
\text { blood from } 72 \\
\text { patients and } 28 \\
\text { healthy controls }\end{array}$ & - & - & $\begin{array}{l}\text { Th17 effector } \\
\text { program }\end{array}$ & $\begin{array}{l}\text { RMRP gene expression } \\
\text { tended to be increased in } \\
\text { patients with } \\
\text { relapsing-remitting form of } \\
\text { MS. }\end{array}$ & $\begin{array}{l}\text { Ghaiad et al. } \\
(2020)\end{array}$ \\
\hline $\begin{array}{l}\text { Rheumatoid } \\
\text { arthritis (RA) }\end{array}$ & $\begin{array}{l}\text { Peripheral blood } \\
\text { from } 20 \text { RA patients } \\
\text { and } 18 \text { healthy } \\
\text { matched controls }\end{array}$ & - & - & - & $\begin{array}{l}\text { RMRP expression was } \\
\text { upregulated in T cells of RA } \\
\text { patients and correlated with } \\
\text { disease duration. }\end{array}$ & $\begin{array}{l}\text { Moharamoghli } \\
\text { et al. (2019) }\end{array}$ \\
\hline $\begin{array}{l}\text { Major depressive } \\
\text { disorder (MDD) }\end{array}$ & $\begin{array}{l}\text { Peripheral blood } \\
\text { from } 29 \text { MDD } \\
\text { patients and } 29 \\
\text { matched healthy } \\
\text { controls }\end{array}$ & - & $\begin{array}{l}\text { Adult male BALB/c } \\
\text { mice }\end{array}$ & - & $\begin{array}{l}\text { RMRP was downregulated } \\
\text { in MDD patients and mouse } \\
\text { model. It was correlated } \\
\text { with depression severity. }\end{array}$ & $\begin{array}{l}\text { Seki et al. } \\
(2019)\end{array}$ \\
\hline
\end{tabular}

\section{DISCUSSION}

Over-expression of RMRP has been reported in numerous types of cancers such as those originated from bladder, colorectal, lung, breast and gastric tissues. Moreover, up-regulation of RMRP is a marker of poor prognosis in these types of cancers. The results of in vitro and in vivo studies consistently verify this function for RMRP with a single exception in the hepatocellular carcinoma.
In spite of vast mechanistical studies about the role of RMRP, the net situation of RMRP as a diagnostic marker in cancer has not been evaluated yet.

RMRP serves as a sponge for miR-206, miR-613, miR1-3p, and miR-217. Among these miRNAs, the functional interaction between RMRP and miR-206 has been approved in different tissues. In addition to these miRNAs, expressions of tens of miRNAs have been altered following RMRP silencing, 
implying the vast extent of RMRP/miRNA network (Tang et al., 2019). Functional annotation of dysregulated miRNAs depicted their relevance with structural molecular functions, extracellular matrix elements, retinoid/isoprenoid binding, functions of cytokines and IFN- $\alpha /-\beta$ receptor binding (Tang et al., 2019). Almost all of these functions are related with the carcinogenesis process. Therefore, a possible route for participation of RMRP in this process is its interactions with miRNAs. One of the pathways being influenced RMRP is stem cells metabolism (Tang et al., 2019) which accords with the formerly reported role of RMRP in giving permission to cancer cells for infinite proliferation via interplay with TERT (Maida et al., 2009).

In addition to the mentioned malignant conditions, dysregulation of RMRP has been reported in ischemic myocardial injury, cardiac fibrosis, ischemic stroke, multiple sclerosis, rheumatoid arthritis and major depressive disorder. Evidence for contribution of RMRP in the pathogenesis of major depressive disorder has come from both human and rodent studies (Seki et al., 2019). Moreover decreased levels of this lncRNA in the circulation of patients potentiate it as a biomarker for this neuropsychiatric condition (Seki et al., 2019). The role of RMRP in construction of the nuclear RNase MRP complex and its function in the processing of ribosomal RNA, its effects in the regulation of epigenetic mechanisms and its interactions with the telomerase reverse transcriptase catalytic subunit have been suggested as possible mechanisms of participation of RMRP in major depressive disorder (Seki et al., 2019). Therefore, RMRP is involved in the development of diverse disorders. This finding is in accordance with the ubiquitous expression of RMRP in human tissues. Functionally, the majority of effects of RMRP in the pathogenesis of these disorders are explained by the regulatory role of this lncRNA in the mitochondrial functions particularly apoptotic pathways regulated by this organelle. In addition, based on the interaction between RMRT and miRNAs regulating

\section{REFERENCES}

An, J., Chen, Z., Ma, Q., Li, Y., and Shi, F. (2020). Liraglutide improves atherosclerosis by regulating long non-coding RNA RMRP/miR-128-1-5P/Gadd45g axis. Eur. Rev. Med. Pharmacol. Sci. 24, 2725-2737.

Birney, E., Stamatoyannopoulos, J., Dutta, A., Guigó, R., Gingeras, T., Margulies, E., et al. (2007). Baylor college of medicine human genome sequencing center; washington university genome sequencing center; broad institute; children's hospital oakland research institute. identification and analysis of functional elements in $1 \%$ of the human genome by the ENCODE pilot project. Nature 447, 799-816.

Boya, P., and Kroemer, G. (2008). Lysosomal membrane permeabilization in cell death. Oncogene 27, 6434-6451. doi: 10.1038/onc.2008.310

Cao, H., Liu, Z., Huang, P., Yue, Y., and Xi, J. (2019). IncRNA-RMRP promotes proliferation, migration and invasion of bladder cancer via miR-206. Eur. Rev. Med. Pharmacol. Sci. 23, 1012-1021.

Carninci, P., Kasukawa, T., Katayama, S., Gough, J., Frith, M., Maeda, N., et al. (2005). The transcriptional landscape of the mammalian genome. Science 309, 1559-1563. doi: 10.1126/science.1112014

Chang, D. D., and Clayton, D. A. (1987). A mammalian mitochondrial RNA processing activity contains nucleus-encoded RNA. Science 235, 1178-1184. doi: 10.1126/science.2434997

Consortium, E. P. (2012). An integrated encyclopedia of DNA elements in the human genome. Nature 489:57. doi: 10.1038/nature11247 cytokine activity, modulation of immune function is another mechanism of participation of RMRT in the development of these disorders especially rheumatoid arthritis and multiple sclerosis.

A major limitation of most of studies that assessed expression of RMRP in cancer patients is the small sample size and lack of validation of the obtained results in independent cohorts. Moreover, they have not assessed expression of this lncRNA in the circulation to unravel its potential as non-invasive biomarker.

Taken together, RMRP is an lncRNA whose dysregulation and somatic mutations have been demonstrated in solid and hematological malignancies. However, the association between the observed mutations and altered expression of this lncRNA has not been assessed yet. Thus, this field should be explored in future studies.

\section{FUTURE DIRECTIONS}

Recent advances in high throughput sequencing techniques have facilitated identification of molecular counterparts of lncRNAs. Further attempts in this field would identify additional mRNA and miRNA molecules that function in upstream and downstream of RMRP, thus extending the functional network through which this IncRNA exerts its effects. Comprehensive assessment of these network would help in recognition of the most appropriate therapeutic targets for treatment of RMRPassociated disorders.

\section{AUTHOR CONTRIBUTIONS}

MT and SG-F wrote the draft and revised it. $\mathrm{BH}, \mathrm{TA}$, and $\mathrm{HH}$ collected the data and designed the tables and figures. All authors approved submitted version.

Dahariya, S., Paddibhatla, I., Kumar, S., Raghuwanshi, S., Pallepati, A., and Gutti, R. K. (2019). Long non-coding RNA: classification, biogenesis and functions in blood cells. Mol. Immunol. 112, 82-92. doi: 10.1016/j.molimm.2019.04.011

Feng, W., Li, L., Xu, X., Jiao, Y., and Du, W. (2017). Up-regulation of the long noncoding RNA RMRP contributes to glioma progression and promotes glioma cell proliferation and invasion. Arch. Med. Sci. 13:1315. doi: 10.5114/aoms.2017. 66747

Ghaiad, H. R., Elmazny, A. N., Nooh, M. M., El-Sawalhi, M. M., and Shaheen, A. A. (2020). Long noncoding RNAs APOA1-AS, IFNG-AS1, RMRP and their related biomolecules in Egyptian patients with relapsing-remitting multiple sclerosis: Relation to disease activity and patient disability. J. Adv. Res. 21, 141-150. doi: 10.1016/j.jare.2019.10.012

Greco, S., Zaccagnini, G., Perfetti, A., Fuschi, P., Valaperta, R., Voellenkle, C., et al. (2016). Long noncoding RNA dysregulation in ischemic heart failure. J. Transl. Med. 14:183.

Guo, K., and Jin, F. (2015). NFAT5 promotes proliferation and migration of lung adenocarcinoma cells in part through regulating AQP5 expression. Biochem. Biophys. Res. Commun. 465, 644-649. doi: 10.1016/j.bbrc.2015.08.078

Han, Y., Cai, Y., Lai, X., Wang, Z., Wei, S., Tan, K., et al. (2020). lncRNA RMRP prevents mitochondrial dysfunction and cardiomyocyte apoptosis via the miR1-5p/hsp70 Axis in LPS-induced sepsis mice. Inflammation 43, 605-618. doi: 10.1007/s10753-019-01141-8

Hauck, F., Voss, R., Urban, C., and Seidel, M. G. (2018). Intrinsic and extrinsic causes of malignancies in patients with primary immunodeficiency disorders. J. Allergy Clin. Immunol. 141, 59-68. doi: 10.1016/j.jaci.2017.06.009 
Hermanns, P., Bertuch, A. A., Bertin, T. K., Dawson, B., Schmitt, M. E., Shaw, C., et al. (2005). Consequences of mutations in the non-coding RMRP RNA in cartilage-hair hypoplasia. Hum. Mol. Genet. 14, 3723-3740. doi: 10.1093/hmg/ ddi 403

Hongfeng, Z., Andong, J., Liwen, S., Mingping, B., Xiaowei, Y., Mingyong, L., et al. (2020). lncRNA RMRP knockdown suppress hepatocellular carcinoma biological activities via regulation miRNA-206/TACR1. J. Cell. Biochem. 121, 1690-1702. doi: $10.1002 /$ jcb. 29404

Huang, B., Zhai, W., Hu, G., Huang, C., Xie, T., Zhang, J., et al. (2016). MicroRNA206 acts as a tumor suppressor in bladder cancer via targeting YRDC. Am. J. Transl. Res. 8:4705.

Karin, M., Cao, Y., Greten, F. R., and Li, Z.-W. (2002). NF-kB in cancer: from innocent bystander to major culprit. Nat. Rev. Cancer. 2, 301-310. doi: 10.1038/ nrc780

Kong, F., Jin, J., Lv, X., Han, Y., Liang, X., Gao, Y., et al. (2019). Long noncoding RNA RMRP upregulation aggravates myocardial ischemia-reperfusion injury by sponging miR-206 to target ATG3 expression. Biomed. Pharmacother. 109, 716-725. doi: 10.1016/j.biopha.2018.10.079

Kostjukovits, S., Degerman, S., Pekkinen, M., Klemetti, P., Landfors, M., Roos, G., et al. (2017). Decreased telomere length in children with cartilage-hair hypoplasia. J. Med. Genet. 54, 365-370. doi: 10.1136/jmedgenet-2016-104279

Li, X., and Sui, Y. (2020). Valproate improves middle cerebral artery occlusioninduced ischemic cerebral disorders in mice and oxygen-glucose deprivationinduced injuries in microglia by modulating RMRP/PI3K/Akt axis. Brain Res. 1747:147039. doi: 10.1016/j.brainres.2020.147039

Lin, Y., Leng, Q., Zhan, M., and Jiang, F. (2018). A plasma long noncoding RNA signature for early detection of lung cancer. Transl. Oncol. 11, 1225-1231. doi: 10.1016/j.tranon.2018.07.016

Macfarlane, L.-A., and Murphy, P. R. (2010). MicroRNA: biogenesis, function and role in cancer. Curr. Genom. 11, 537-561. doi: 10.2174/138920210793175895

Maida, Y., Yasukawa, M., Furuuchi, M., Lassmann, T., Possemato, R., Okamoto, N., et al. (2009). An RNA-dependent RNA polymerase formed by TERT and the RMRP RNA. Nature. 461, 230-235. doi: 10.1038/nature08283

Mattick, J. S., Taft, R. J., and Faulkner, G. J. (2010). A global view of genomic information-moving beyond the gene and the master regulator. Trends Genet. 26, 21-28. doi: 10.1016/j.tig.2009.11.002

Moharamoghli, M., Hassan-Zadeh, V., Dolatshahi, E., Alizadeh, Z., and Farazmand, A. (2019). The expression of GAS5, THRIL, and RMRP lncRNAs is increased in $\mathrm{T}$ cells of patients with rheumatoid arthritis. Clin. Rheumatol. 38, 3073-3080. doi: 10.1007/s10067-019-04694-z

Nguyen, A., Martin Silva, N., de Boysson, H., Damaj, G., and Aouba, A. (1718). Diffuse large B-cell lymphoma chemotherapy reveals a combined immunodeficiency syndrome in cartilage hair hypoplasia. Swiss Med. Weekly. 2018:148.

Palazzo, A. F., and Lee, E. S. (2015). Non-coding RNA: what is functional and what is junk? Front. Genet. 6:2. doi: 10.3389/fgene.2015.00002

Pan, J., Zhang, D., Zhang, J., Qin, P., and Wang, J. (2019). LncRNA RMRP silence curbs neonatal neuroblastoma progression by regulating microRNA206/tachykinin-1 receptor axis via inactivating extracellular signal-regulated kinases. Cancer Biol. Ther. 20, 653-665. doi: 10.1080/15384047.2018.155 0568

Park, J., and Jeong, S. (2015). Wnt activated $\beta$-catenin and YAP proteins enhance the expression of non-coding RNA component of RNase MRP in colon cancer cells. Oncotarget 6:34658. doi: 10.18632/oncotarget.5778

Rheinbay, E., Parasuraman, P., Grimsby, J., Tiao, G., Engreitz, J. M., Kim, J., et al. (2017). Recurrent and functional regulatory mutations in breast cancer. Nature $547,55-60$.

Rosenbluh, J., Nijhawan, D., Chen, Z., Wong, K. K., Masutomi, K., and Hahn, W. C. (2011). RMRP is a non-coding RNA essential for early murine development. PLoS One 6:e26270. doi: 10.1371/journal.pone.0026270

Rosenzweig, R., Nillegoda, N. B., Mayer, M. P., and Bukau, B. (2019). The Hsp70 chaperone network. Nat. Rev. Mol. Cell. Biol. 20, 665-680.

Sathishkumar, D., Gach, J. E., Ogboli, M., Desai, M., Cole, T., Högler, W., et al. (2018). Cartilage hair hypoplasia with cutaneous lymphomatoid granulomatosis. Clin. Exper. Dermatol. 43, 713-717. doi: 10.1111/ced. 13543

Seki, T., Yamagata, H., Uchida, S., Chen, C., Kobayashi, A., Kobayashi, M., et al. (2019). Altered expression of long noncoding RNAs in patients with major depressive disorder. J. Psychiatric Res. 117, 92-99. doi: 10.1016/j.jpsychires. 2019.07.004
Shao, C., Liu, G., Zhang, X., Li, A., and Guo, X. (2020). Long noncoding RNA RMRP suppresses the tumorigenesis of hepatocellular carcinoma through targeting microRNA-766. OncoTargets Ther. 13:3013. doi: 10.2147/ott.s243736

Shao, Y., Ye, M., Li, Q., Sun, W., Ye, G., Zhang, X., et al. (2016). LncRNA-RMRP promotes carcinogenesis by acting as a miR-206 sponge and is used as a novel biomarker for gastric cancer. Oncotarget 7:37812.

Son, H. J., Choi, E. J., Yoo, N. J., and Lee, S. H. (2019). Somatic mutations in longnon-coding RNA RMRP in acute leukemias. Pathol. Res. Practice. 215:152647. doi: 10.1016/j.prp.2019.152647

Son, H. J., Mo, H. Y., Choi, E. J., Yoo, N. J., and Lee, S. H. (2020). Promoter mutation analysis of long-non-coding RNA RMRP gene in solid tumors. Pathol. Oncol. Res. 26, 2809-2810. doi: 10.1007/s12253-019-00723-z

Stark, B. C., Kole, R., Bowman, E. J., and Altman, S. (1978). Ribonuclease P: an enzyme with an essential RNA component. Proc. Natl. Acad. Sci. 75, 3717-3721.

Sun, S.-C. (2011). Non-canonical NF-кB signaling pathway. Cell Res. 21, 71-85. doi: $10.1038 /$ cr.2010.177

Sun, X., Zhang, R., Liu, M., Chen, H., Chen, L., Luo, F., et al. (2019). Rmrp mutation disrupts chondrogenesis and bone ossification in zebrafish model of cartilagehair hypoplasia via enhanced Wnt/ $\beta$-catenin signaling. J. Bone Mineral Res. 34, 2101-2116. doi: 10.1002/jbmr.3820

Takekawa, M., and Saito, H. (1998). A family of stress-inducible GADD45-like proteins mediate activation of the stress-responsive MTK1/MEKK4 MAPKKK. Cell 95, 521-530. doi: 10.1016/s0092-8674(00)81619-0

Tamura, R. E., de Vasconcellos, J. F., Sarkar, D., Libermann, T. A., Fisher, P. B., and Zerbini, L. F. (2012). GADD45 proteins: central players in tumorigenesis. Curr. Mol. Med. 12, 634-651. doi: 10.2174/156652412800619978

Tang, L., Wang, Y., Wang, H., Xu, B., Ji, H., Xu, G., et al. (2019). Long noncodingRNA component of mitochondrial RNA processing endoribonuclease is involved in the progression of cholangiocarcinoma by regulating microRNA217. Cancer Sci. 110:2166. doi: 10.1111/cas.14074

Taskinen, M., Jeskanen, L., Karjalainen-Lindsberg, M.-L., Mäkitie, A., Mäkitie, O., and Ranki, A. (2013). Combating cancer predisposition in association with idiopathic immune deficiency: a recurrent nodal and cutaneous T-cell lymphoproliferative disease in a patient with cartilage-hair hypoplasia. Clin. Lymphoma Myeloma Leukemia. 13, 73-76. doi: 10.1016/j.clml.2012.06.005

Vakkilainen, S., Skoog, T., Einarsdottir, E., Middleton, A., Pekkinen, M., Öhman, T., et al. (2019a). The human long non-coding RNA gene RMRP has pleiotropic effects and regulates cell-cycle progression at G2. Sci. Rep. 9, 1-9.

Vakkilainen, S., Taskinen, M., Klemetti, P., Pukkala, E., and Mäkitie, O. (2019b). A 30-year prospective follow-up study reveals risk factors for early death in cartilage-hair hypoplasia. Front. Immunol. 10:1581. doi: 10.3389/fimmu.2019. 01581

Wang, J., Xiao, T., and Zhao, M. (2019). MicroRNA-675 directly targets MAPK1 to suppress the oncogenicity of papillary thyroid cancer and is sponged by long non-coding RNA RMRP. Oncotargets Ther. 12, 7307-7321. doi: 10.2147/ott. s213371

Wu, J., Liu, T., Rios, Z., Mei, Q., Lin, X., and Cao, S. (2017). Heat shock proteins and cancer. Trends Pharmacol. Sci. 38, 226-256.

Yang, M., Ke, H., and Zhou, W. (2020). LncRNA RMRP promotes cell proliferation and invasion through miR-613/NFAT5 axis in non-small cell lung cancer. Onco Targets Ther. 13:8941. doi: 10.2147/ott.s255126

Zhang, S. Y., Huang, S. H., Gao, S. X., Wang, Y. B., Jin, P., and Lu, F. J. (2019). Upregulation of lncRNA RMRP promotes the activation of cardiac fibroblasts by regulating miR-613. Mol. Med. Rep. 20, 3849-3857.

Zhou, N., He, Z., Tang, H., Jiang, B., and Cheng, W. (2019). LncRNA RMRP/miR613 axis is associated with poor prognosis and enhances the tumorigenesis of hepatocellular carcinoma by impacting oncogenic phenotypes. Am. J. Transl. Res. 11:2801.

Conflict of Interest: The authors declare that the research was conducted in the absence of any commercial or financial relationships that could be construed as a potential conflict of interest.

Copyright $\odot 2021$ Hussen, Azimi, Hidayat, Taheri and Ghafouri-Fard. This is an open-access article distributed under the terms of the Creative Commons Attribution License (CC BY). The use, distribution or reproduction in other forums is permitted, provided the original author(s) and the copyright owner(s) are credited and that the original publication in this journal is cited, in accordance with accepted academic practice. No use, distribution or reproduction is permitted which does not comply with these terms. 